\title{
Endovascular treatment for acute basilar artery occlusion: a single center retrospective observational study
}

\author{
Xuan Sun ${ }^{1}$, Xu Tong ${ }^{1}$, Feng Gao ${ }^{1}$, Huiting Lao ${ }^{2}$ and Zhongrong Miao ${ }^{1 *}$ [D
}

\begin{abstract}
Background: Endovascular treatment (EVT) is now considered the gold standard for select patient populations with anterior circulation stroke; however, data on the treatment of posterior circulation stroke are less clear. This study aims to determine the characteristics and treatment outcomes of patients with acute basilar artery occlusion (BAO) and to evaluate the effectiveness and safety of EVT for patients with acute BAO in a high-volume stroke center.

Methods: This study included 187 consecutive patients with acute BAO who underwent EVT from January 2012 to July 2018 in the Beijing Tiantan Hospital. The baseline characteristics, procedure parameters, and functional outcome were assessed.

Results: Among the 187 patients, 138 (73.8\%) underwent mechanical thrombectomy with a stent retriever, 33 (17.6\%) underwent direct intracranial angioplasty (balloon dilation and/or stent implantation) for underlying severe intracranial atherosclerotic disease, and 91 (48.7\%) underwent combined mechanical thrombectomy and angioplasty. Successful recanalization [modified Thrombolysis in Cerebral Infarction (mTICl) grade 2b-3] was achieved in 158 patients (84.5\%). Overall, the rates of functional independence [modified Rankin Scale (mRS) 0-2] and favorable outcome (mRS 0-3) at 90 days were 36.4 and 49.2\%, respectively, and 90-day all-cause mortality was $20.3 \%$.
\end{abstract}

Conclusion: EVT was effective and safe for treating patients with acute BAO.

Keywords: Acute ischemic stroke, Basilar artery occlusion, Endovascular treatment

\section{Background}

Acute ischemic stroke (AIS) caused by basilar artery occlusion (BAO) has devastating effects on patients and has high morbidity and mortality rates. Among patients treated conventionally with antiplatelets or anticoagulation, the rate of poor outcomes remains high $(80 \%)$ despite recent advances in stroke care [1,2]. In the registry of Basilar Artery International Cooperation Study (BASICS) [1], the proportion of favorable outcomes [modified Rankin Scale (mRS) 0-3] in the antithrombotic treatment group was $21.9,33.9 \%$ in the intravenous thrombolysis (IVT) group, and $17.5 \%$ in the intra-arterial treatment (local thrombolysis) group. The mortality

\footnotetext{
*Correspondence: miaozhongrong123@126.com

'Department of Interventional Neurology, Beijing Tiantan Hospital, Capital Medical University, 119 South Fourth Ring West Road, Fengtai District, Beijing, China

Full list of author information is available at the end of the article
}

rates in the groups were $30.6,33.9$, and $40.6 \%$, respectively. However, new-generation endovascular treatment (EVT) devices such as "Solitaire" and "Trevo" stent retrievers were not used in the BASICS [3, 4].

Modern EVT techniques, particularly mechanical thrombectomy (MT) with stent retrievers, have been validated by several large randomized controlled trials $[5,6]$. Recently, more studies embracing the New England Center Posterior Circulation Registry have shown no significant differences in the clinical features of posterior circulation stroke (PCS) compared with those with anterior circulation stroke (ACS) and a more benign outcome in patients with PCS $[7,8]$. The efficacy and safety of MT in patients with acute Bao are uncertain due to the lack of case series and case reports showing the efficacy and safety of posterior circulation thrombectomy in a single-arm study. Our intention was to depict our experience with EVT for acute 
$\mathrm{BAO}$ at a high-volume stroke center in China and to assess its feasibility and safety.

\section{Methods}

\section{Patient selection}

We performed a retrospective analysis of consecutive patients presenting with BAO treated by EVT in Beijing Tiantan Hospital from January 2012 to July 2018. IVT with tissue plasminogen activator (tPA) was acceptable before EVT, consistent with current guidelines [9]. The protocol was approved by the Institutional Review Board of Beijing Tiantan Hospital.

Plain computed tomography (CT) of the brain was performed first, followed by either computed tomography angiography (CTA) or magnetic resonance imaging (MRI) with magnetic resonance angiography (MRA) to confirm the presence of acute BAO and to exclude both large brainstem infarction and intracranial bleeding. Imaging modality selection relied on physician preferences and the logistics of scheduling the procedures. We retrospectively analyzed clinical and radiologic data of these patients, including age; sex; stroke risk factors including hypertension, diabetes mellitus, hypercholesterolemia, and current smoking; initial stroke severity as expressed by the National Institutes of Health Stroke Scale (NIHSS) score; initial imaging modality; prior use of IVT; type of EVT devices; onset to puncture time; procedure time; onset to recanalization time; collateral status; and etiology of stroke according to the Trial of Org 10,172 in Acute Stroke Treatment (TOAST) classification [10]. The modality of treatment was a joint decision between the neurointerventionalist and the stroke team taking care of the patient.

\section{Endovascular treatment}

All EVT procedures were performed by a neurointerventionalist with more than 50 cases of experience in neurovascular intervention in MT for AIS. Cerebral angiography and EVT were performed under general anesthesia or conscious sedation after evaluation by a dedicated anesthesiology team. The thrombectomy technique was chosen at the interventionalist's discretion, using either a stent retriever or aspiration first, with a possible switch to another strategy in case of recanalization failure [modified Thrombolysis in Cerebral Infarction (mTICI) grade 0-2a] with the first approach. If underlying intracranial atherosclerotic stenosis (ICAS) was revealed, intracranial angioplasty or stenting was performed when needed. If patients who were antiplatelet-naive undergoing angioplasty and/or stenting received an loading dose of aspirin (300 mg) and clopidogrel $(300 \mathrm{mg})$ orally or via a nasogastric tube immediately after the intervention. During operative bridging with intravenous IIb/IIIa inhibitor was also
Table 1 Values are numbers with percentages in parentheses, unless indicated otherwise

\begin{tabular}{|c|c|}
\hline Variable name & Overall cohort $(n=187)$ \\
\hline \multicolumn{2}{|l|}{ Demographic data } \\
\hline Age, mean (SD), years & $60(10)$ \\
\hline Male sex & $157(84.0)$ \\
\hline \multicolumn{2}{|l|}{ Vascular risk factors } \\
\hline Hypertension & $133(71.1)$ \\
\hline Diabetes mellitus & $51(27.3)$ \\
\hline Dyslipidemia & $30(16.0)$ \\
\hline Coronary heart disease & $21(11.2)$ \\
\hline Atrial fibrillation & $11(5.9)$ \\
\hline Prior stroke & $37(19.8)$ \\
\hline Premorbid $\mathrm{mRS} \geq 3$ & $9(4.8)$ \\
\hline Current smoking & $70(37.4)$ \\
\hline \multicolumn{2}{|l|}{ Clinical characteristics } \\
\hline $\mathrm{SBP}$, mean (SD), mmHg & $160(25)$ \\
\hline NIHSS score, median (IQR) & $22(10-34)$ \\
\hline GCS score, median (IQR) & $8(3-13)$ \\
\hline pc-ASPECTS on DWI, median (IQR) & $6(5-8)$ \\
\hline PMI on DWI, median (IQR) & $2(1-4)$ \\
\hline \multicolumn{2}{|l|}{ Occlusion site } \\
\hline Proximal BA (including intracranial VA) & $104(55.6)$ \\
\hline Middle BA & $54(28.9)$ \\
\hline Distal BA & $29(15.5)$ \\
\hline Tandem lesion & $25(13.4)$ \\
\hline Underlying ICAS & $117(62.6)$ \\
\hline \multicolumn{2}{|l|}{ Presence of PcomA } \\
\hline No & $68(36.4)$ \\
\hline Unilateral & $88(47.1)$ \\
\hline Bilateral & $31(16.6)$ \\
\hline \multicolumn{2}{|l|}{ ASITN/SIR collateral system } \\
\hline Grade $0-1$ & $78(41.7)$ \\
\hline Grade 2 & $87(46.5)$ \\
\hline Grade 3-4 & $22(11.8)$ \\
\hline \multicolumn{2}{|l|}{ Stroke subtype by TOAST criteria } \\
\hline Large artery arteriosclerosis & $151(80.7)$ \\
\hline Cardioembolic & $29(15.5)$ \\
\hline Other or unknown etiology & $7(3.7)$ \\
\hline
\end{tabular}

Abbreviations: $B A$ basilar artery, DWI diffusion weighted imaging, GCS Glasgow Coma Scale, ICAS intracranial atherosclerotic stenosis, IQR interquartile range, mRS modified Rankin Scale, NIHSS National Institutes of Health Stroke Scale, pc-ASPECTS posterior circulation Acute Stroke Prognosis Early CT Score, PMI Pons-Midbrain Index, SBP systolic blood pressure, SD standard deviation, TOAST Trial of Org 10,172 in Acute Stroke Treatment, VA vertebral artery

allowed at the operator's discretion. Dual antiplatelet therapy was preserved for at least 3 months, followed by aspirin or clopidogrel for life. 


\section{Image interpretation}

Pretreatment neurovascular images, including posterior circulation Acute Stroke Prognosis Early CT Score (pcASPECTS), Pons-Midbrain Index based on diffusionweighted imaging, and two previous collateral scales [posterior communicating artery (PCoa) and American Society of Interventional and Therapeutic Neuroradiology/Society of Interventional Radiology (ASITN/SIR)] [11, 12] described in the setting of $\mathrm{BAO}$, were retrospectively interpreted by two independent trained neurointerventionalists blinded to clinical data. A third neurointeventionalist with 20 years' experience was involved to resolve any disputes. All collateral scales mentioned above were evaluated by digital subtraction angiography.

\section{Outcome measurement}

Primary effectiveness outcome measures were functional independence and favorable outcome at 90 days after the procedure. Functional independence was defined as an $m R S$ score of $\leq 2$. Favorable outcome was defined as an mRS score of $\leq 3$, in accordance with the BASICS definition [1]. The mRS was assessed by blinded trained interviewers over the phone using a standardized interview protocol. Other effectiveness outcome measures included the rates of successful recanalization (mTICI 2b3 ) and complete recanalization $(\mathrm{mTICI}=3)$ [13].

Safety outcome measures were 90-day mortality and rates of intracerebral hemorrhage and symptomatic intracerebral hemorrhage $(\mathrm{SICH})$ within $24 \mathrm{~h}$. $\mathrm{SICH}$ was defined on the basis of the European Cooperative Acute Stroke Study III (ECASS III) criteria [14].

\section{Statistical analysis}

Study data were collected on standard forms, evaluated for completeness, and double keyed into an EpiData statistics data document. Baseline and outcome data were

Table 2 Values are numbers with percentages in parentheses, unless indicated otherwise

\begin{tabular}{|c|c|}
\hline Variable name & Overall cohort $(n=187)$ \\
\hline \multicolumn{2}{|l|}{ Procedural features } \\
\hline Prior use of intravenous tPA & $36(19.3)$ \\
\hline General anaesthesia & $147(78.6)$ \\
\hline Use of Solitaire retriever & $138(73.8)$ \\
\hline \multicolumn{2}{|l|}{ No. of passes } \\
\hline$\leq 1$ & $70(50.7)$ \\
\hline 2 & $38(27.5)$ \\
\hline$\geq 3$ & $30(21.7)$ \\
\hline -arterial tPA or Urokinase & $43(23.0)$ \\
\hline Balloon angioplasty & $101(54.0)$ \\
\hline Stenting & $93(49.7)$ \\
\hline Onset to puncture time, median (IQR), hours & $7(5-10)$ \\
\hline Procedure time, median (IQR), hours & $1.5(1-2)$ \\
\hline Onset to recanalization time, median (IQR), hours & $8.5(6-11)$ \\
\hline \multicolumn{2}{|l|}{ Procedural complications } \\
\hline Embolization in distal or new territory & $18(9.6)$ \\
\hline Arterial dissection & $6(3.2)$ \\
\hline Arterial perforation & $8(4.3)$ \\
\hline Target-vessel reocclusion & $17(9.1)$ \\
\hline \multicolumn{2}{|l|}{ Outcome measures } \\
\hline Successful recanalization (mTICl 2b-3) & $158(84.5)$ \\
\hline Complete recanalization (mTICl 3) & $126(67.4)$ \\
\hline Hemorrhagic transformation within $24 \mathrm{~h}$ & $29(15.5)$ \\
\hline SICH (ECASS III definition) within $24 \mathrm{~h}$ & $8(4.3)$ \\
\hline Functional independence (mRS 0-2) at 90 days & $68(36.4)$ \\
\hline Favorable outcome (mRS 0-3) at 90 days & $92(49.2)$ \\
\hline Mortality at 90 days & $38(20.3)$ \\
\hline
\end{tabular}

Abbreviations: ECASS European Cooperative Acute Stroke Study, IQR interquartile range, mRS modified Rankin Scale, $m$ TICI modified Thrombolysis in Cerebral Infarction, SICH symptomatic intracerebral hemorrhage, $t P A$ tissue Plasminogen Activator 
described using means (standard deviations) and/or medians (25th and 75th percentiles) for continuous variables. Frequencies and/or proportions were used for categorical variables. Pearson's chi-square test or Fisher's exact test was used to compare the differences in frequencies and/or proportions. All tests were two-tailed, and statistical significance was determined at an $\alpha$ level of 0.05 . All statistical analyses were performed with the statistical software packages $\mathrm{R}$ (http://www.R-project. org, The R Foundation) and Empowerstats (http://www. empowerstats.com, X\&Y Solutions, Inc., Boston, MA).

Data availability statement: All data generated or analyzed during this study are included in this published article [and its Additional file 1].

\section{Results}

A total of 187 patients with BAO underwent EVT during the study period. Their mean age was $60 \pm 10$ years, with a median admission NIHSS score of 22 [interquartile range (IQR) 10-34]. Baseline characteristics and procedure and outcome parameters are summarized in Tables 1 and 2. The median time from $\mathrm{BAO}$ onset to puncture was $7 \mathrm{~h}$ (IQR 5-10). In terms of procedure parameters, stent retrievers were more frequently used (73.8\%) than intra-arterial thrombolysis (23.0\%) or stenting (49.7\%). General anesthesia was used in $78.6 \%$ of the cases, and the median procedure length was 1.5 h (IQR 1-2). Successful recanalization (mTICI 2b-3) and complete recanalization (mTICI 3) were achieved in 158 $(84.5 \%)$ and $126(67.4 \%)$ patients, respectively. Intracerebral hemorrhage occurred in 29 (15.5\%) patients. SICH within $24 \mathrm{~h}$ occurred in 8 (4.3\%) patients. Ninety-day functional independence and favorable outcome were achieved in 68 (36.4\%) and 92 (49.2\%) patients, respectively, while mortality at 90 days was $20.3 \%$ (Table 2).

Results from subgroup analysis in patients with acute $\mathrm{BAO}$ are shown in Table 3 and Fig. 1. Of the 187 patients, $117(62.6 \%)$ had underlying ICAS at the occlusion site. Patients with ICAS and those without ICAS showed similar clinical outcomes. There were no significant differences between the two groups in successful recanalization rate $(85.5 \%$ versus $82.9 \% ; P=0.63)$, $\mathrm{SICH}$ within $24 \mathrm{~h}(3.4 \%$ versus $5.7 \% ; P=0.48)$, functional independence $(36.8 \%$ versus $35.7 \% ; P=0.89)$, favorable outcome (53\% versus $42.9 \% ; P=0.18)$ and mortality $(17.1 \%$ versus $25.7 \% ; P=0.16)$ at 90 days. Compared with other patients, patients with tandem vertebrobasilar occlusions appeared as a possible predictor of mortality (44.0\% versus $16.7 \%, P=0.01$ ) and had a lower recanalization rate $(60.0 \%$ versus $88.3 \%, P<0.01)$. No differences in effectiveness and safety outcomes were observed in patients with or without prior use of intravenous tPA $(P>0.05)$. ASITN/SIR collateral scores $\geq 3$ were associated with functional independence $(59.1 \%$ versus $33.3 \%, P=0.03)$ and favorable outcome $(77.3 \%$ versus $45.5 \%, P=0.01)$. Our study demonstrated no difference in successful recanalization, functional independence, and mortality, comparable with results of previous studies from Asian countries. However, our study showed a lower mortality at 90 days compared with that in previous studies from Western countries (Fig. 2).

Table 3 Subgroup Analysis of Clinical Outcomes in ABAO Patients

\begin{tabular}{|c|c|c|c|c|c|c|c|c|c|c|c|c|}
\hline \multirow[t]{3}{*}{ Outcome variables } & \multicolumn{12}{|c|}{ Subgroups } \\
\hline & \multicolumn{3}{|c|}{ Tandem lesion } & \multicolumn{3}{|l|}{ ICAS } & \multicolumn{3}{|c|}{ ASITN/SIR collateral system } & \multicolumn{3}{|c|}{$\begin{array}{l}\text { Prior use of intravenous } \\
\text { tPA }\end{array}$} \\
\hline & $\begin{array}{l}\text { Yes } \\
(n=25)\end{array}$ & $\begin{array}{l}\text { No } \\
(n=162)\end{array}$ & $\begin{array}{l}P \\
\text { value }\end{array}$ & $\begin{array}{l}\text { Yes } \\
(n=117)\end{array}$ & $\begin{array}{l}\text { No } \\
(n=70)\end{array}$ & $\begin{array}{l}P \\
\text { value } \\
\end{array}$ & $\begin{array}{l}\text { Grade } 0-2 \\
(n=165)\end{array}$ & $\begin{array}{l}\text { Grade } 3-4 \\
(n=22)\end{array}$ & $\begin{array}{l}P \\
\text { value }\end{array}$ & $\begin{array}{l}\text { Yes } \\
(n=36)\end{array}$ & $\begin{array}{l}\text { No } \\
(n=151)\end{array}$ & $\begin{array}{l}P \\
\text { value } \\
\end{array}$ \\
\hline $\begin{array}{l}\text { Successful recanalization } \\
\text { (mTICl 2b-3) }\end{array}$ & $\begin{array}{l}15 \\
(60.0)\end{array}$ & $\begin{array}{l}143 \\
(88.3)\end{array}$ & $\begin{array}{l}< \\
0.01\end{array}$ & $\begin{array}{l}100 \\
(85.5)\end{array}$ & $\begin{array}{l}58 \\
(82.9)\end{array}$ & 0.63 & $137(83.0)$ & $21(95.5)$ & 0.21 & $\begin{array}{l}30 \\
(83.3)\end{array}$ & $\begin{array}{l}128 \\
(84.8)\end{array}$ & 0.80 \\
\hline $\begin{array}{l}\text { Complete recanalization } \\
\text { (mTICl 3) }\end{array}$ & $\begin{array}{l}13 \\
(52.0)\end{array}$ & $\begin{array}{l}113 \\
(69.8)\end{array}$ & 0.11 & $77(65.8)$ & $\begin{array}{l}49 \\
(70.0)\end{array}$ & 0.55 & $108(65.5)$ & $18(81.8)$ & 0.15 & $\begin{array}{l}26 \\
(72.2)\end{array}$ & $\begin{array}{l}100 \\
(66.2)\end{array}$ & 0.49 \\
\hline $\begin{array}{l}\text { Hemorrhagic transformation } \\
\text { within } 24 \mathrm{~h}\end{array}$ & $4(16.0)$ & $25(15.4)$ & $\overrightarrow{0}>99$ & $16(13.7)$ & $\begin{array}{l}13 \\
(18.6)\end{array}$ & 0.37 & $26(15.8)$ & $3(13.6)$ & $\overrightarrow{0.99}$ & $7(19.4)$ & $22(14.6)$ & 0.45 \\
\hline $\begin{array}{l}\text { SICH (ECASS III definition) } \\
\text { within } 24 \mathrm{~h}\end{array}$ & $2(8.0)$ & $6(3.7)$ & 0.29 & $4(3.4)$ & $4(5.7)$ & 0.48 & $7(4.2)$ & $1(4.6)$ & $\begin{array}{l}> \\
0.99\end{array}$ & $1(2.8)$ & $7(4.6)$ & $>>.99$ \\
\hline $\begin{array}{l}\text { Functional independence } \\
\text { (mRS 0-2) at } 90 \text { days }\end{array}$ & $7(28.0)$ & $61(37.7)$ & 0.38 & $43(36.8)$ & $\begin{array}{l}25 \\
(35.7)\end{array}$ & 0.89 & $55(33.3)$ & $13(59.1)$ & 0.03 & $\begin{array}{l}15 \\
(41.7)\end{array}$ & $53(35.1)$ & 0.46 \\
\hline $\begin{array}{l}\text { Favorable outcome } \\
\text { (mRS 0-3) at } 90 \text { days }\end{array}$ & $8(32.0)$ & $84(51.9)$ & 0.07 & $62(53.0)$ & $\begin{array}{l}30 \\
(42.9)\end{array}$ & 0.18 & $75(45.5)$ & $17(77.3)$ & 0.01 & $\begin{array}{l}19 \\
(52.8)\end{array}$ & $73(48.3)$ & 0.63 \\
\hline Mortality at 90 days & $\begin{array}{l}11 \\
(44.0)\end{array}$ & $27(16.7)$ & 0.01 & $20(17.1)$ & $\begin{array}{l}18 \\
(25.7)\end{array}$ & 0.16 & $36(21.8)$ & $2(9.1)$ & 0.26 & $6(16.7)$ & $32(21.2)$ & 0.65 \\
\hline
\end{tabular}

Abbreviations: ASITN/SIR American Society of Interventional and Therapeutic Neuroradiology/Society of Interventional Radiology, ECASS European Cooperative Acute Stroke Study, ICAS intracranial atherosclerotic stenosis, mRS modified Rankin Scale, mTICI modified Thrombolysis in Cerebral Infarction, SICH symptomatic intracerebral hemorrhage, $t P A$ tissue Plasminogen Activator 


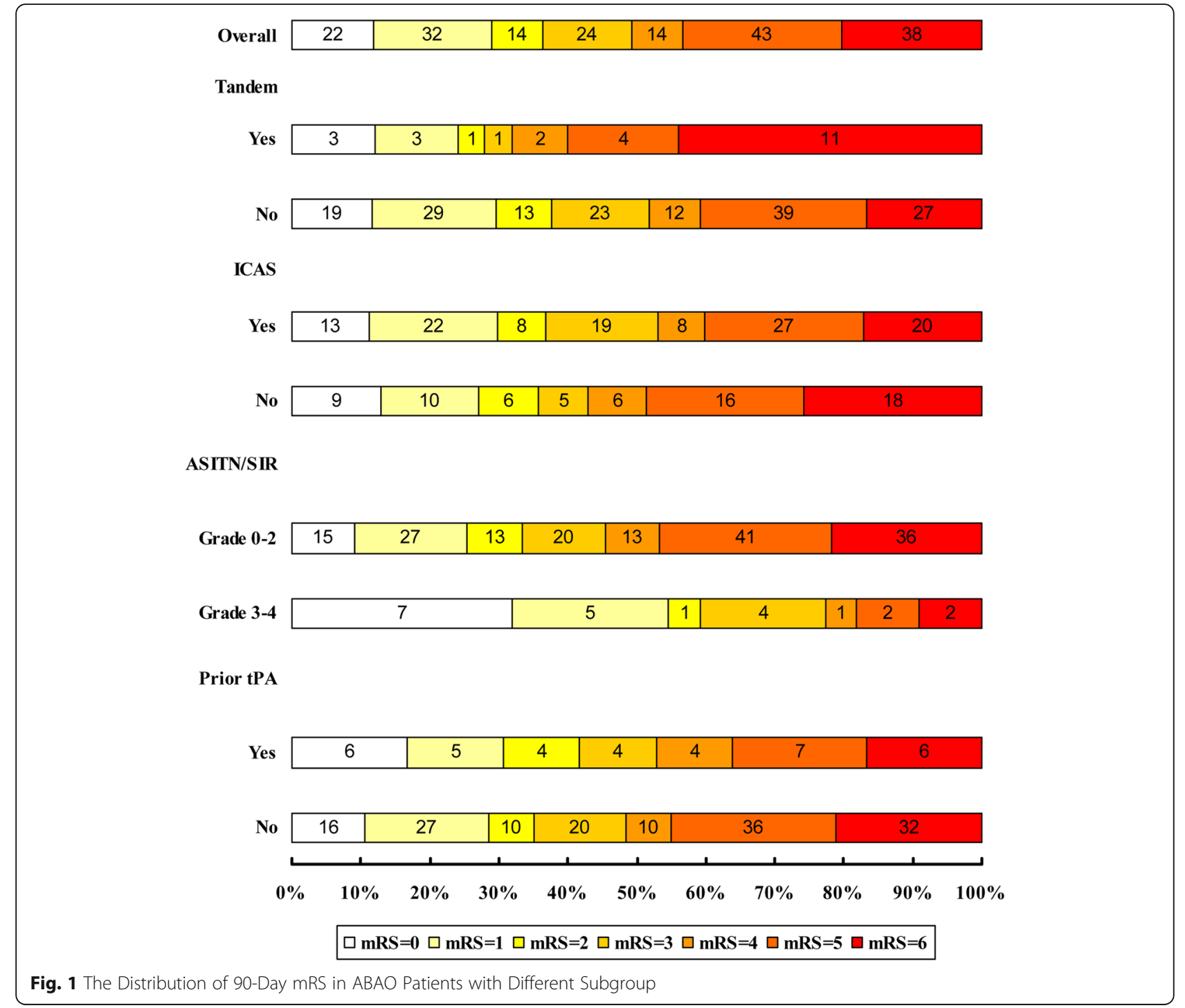

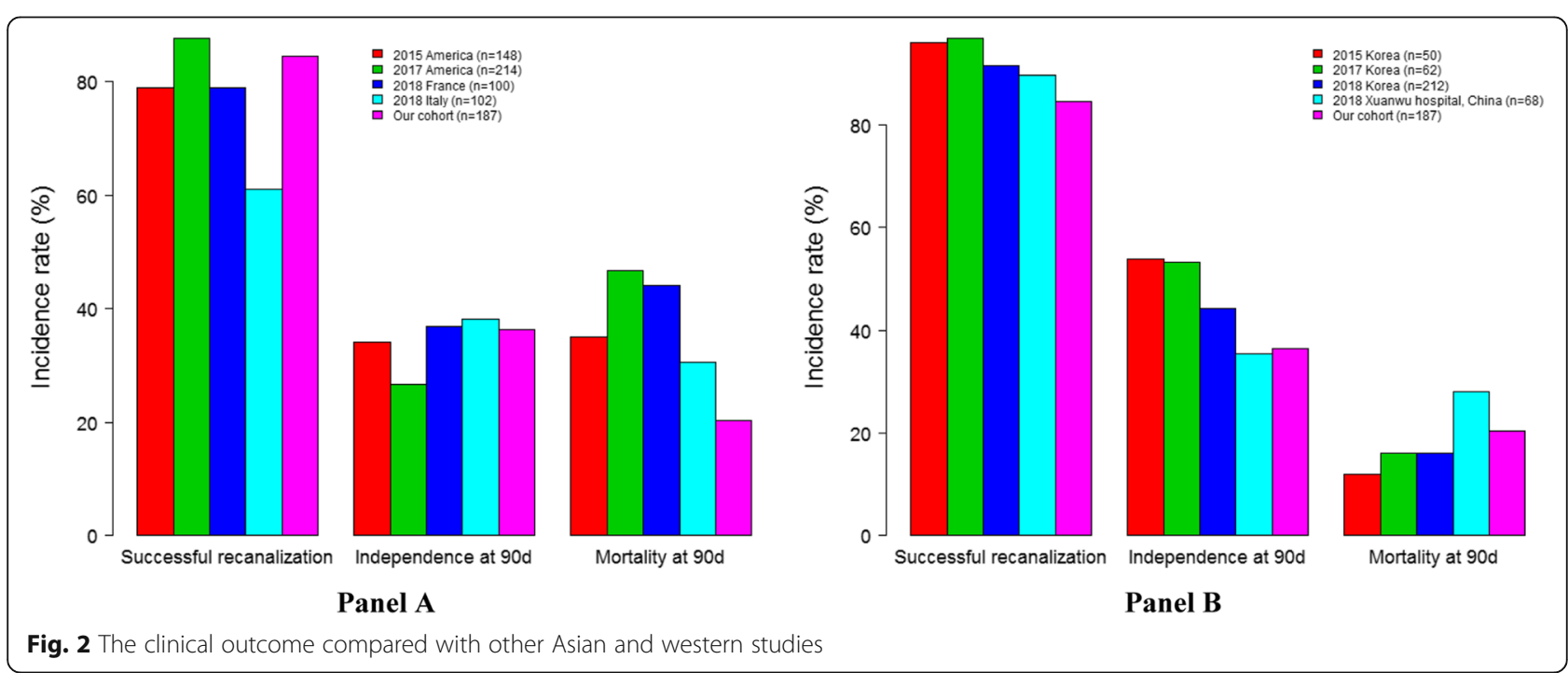




\section{Discussion}

We analyzed the outcome of EVT in patients with BAO at our institution over the past 5 years. In total, 36.4\% of the patients had functional independence (mRS 0-2) and $49.2 \%$ had a favorable outcome (mRS $0-3)$ at 90 days, which were comparable with results of the recently published HERMES meta-analysis of EVT for anterior circulation stroke (46\% versus 56.9\%) [5]. Similar findings were also reported in a recent study on 436 patients with acute large vessel occlusion of anterior and posterior circulation treated with EVT [15]. Our findings demonstrate that when patients were carefully selected and appropriately treated with EVT, those with posterior large vessel occlusions can achieve comparable safety and efficacy to those with anterior large vessel occlusions. The patients with BAO in our cohort achieved a similar clinical outcome to those in other Asian studies [16-19]. However, they had a significantly lower mortality (about 20\%) than those in studies by Western researchers [12, 20-22], although the enrolled patients in our study had a relatively higher NIHSS score (media $n=22)$. This could be explained by the single-center effect attributable to developed interventional techniques and standardized post-operative management. Improving the technology and management of EVT may lead to better recanalization and subsequently to better outcomes. This may also explain why our study had a higher rate of favorable outcomes than previously published studies [23, 24].

Our study shows four major findings: First, EVT combined with IVT for BAO failed to show superior outcomes when compared to EVT alone. The issue of whether prior IVT confers a benefit over direct MT alone has not been settled even for patients with anterior circulation, although studies are underway [25]. Second, tandem vertebrobasilar occlusions were associated with poor outcome and higher mortality. However, a previous study showed that patients with tandem lesions who were comparable with those without tandem vertebrobasilar occlusions presented similar clinical outcomes [26]. Only in recent years has occlusion of the vertebral artery origin been more fully characterized and defined as a potential source of embolic stroke and as a potential predictor of mortality in acute BAO [27]. Third, rescue treatments such as angioplasty with or without stenting and intra-arterial infusion of antiplatelet drugs usually needed in the target artery with underlying ICAS which can make the thrombectomy procedure more complicated [28]. ICAS is an important cause of stent-retriever thrombectomy failure, particularly in Asian patients $[29,30]$. In our study, 117 patients had underlying ICAS, and 75 underwent intracranial angioplasty (balloon dilation and/or stent implantation) after first-line MT. We achieved similar rates of successful recanalization (85.5\% versus $82.9 \%$ ), functional independence $(36.8 \%$ versus $35.7 \%)$, favorable outcome
(53.0\% versus $42.9 \%)$, $\mathrm{SICH}$ (3.4\% versus 5.7\%), and mortality $(17.1 \%$ versus $25.7 \%)$ to those observed in patients without ICAS. Our study suggests that such rescue treatments are effective and safe for treating underlying ICAS in patients with acute BAO. Finally, collateral circulation has been shown to affect recanalization, haemorrhagic transformation, and clinical outcomes in patients with anterior circulation stroke [31-33]. In this series, we used the ASITN/SIR and PCoA scales to assess the collateral status and found a significant correlation between ASITN/SIR and 90-day outcomes, but PCoA collaterals were not significantly associated with clinical outcome.

Our study has several limitations. It was a retrospective, non-randomized controlled study. Data were obtained from a single high-volume stroke center with an interventionalist highly experienced in performing the procedure, so the results may not be replicable in other lower-volume stroke centers. However, the strength of our study is that it represents one of the largest cohorts of patients with BAO treated with EVT. The broad inclusion criteria from stroke severity and time of presentation and variability in procedure parameters allow us to improve our understanding of the specific needs of this patient population and appropriate therapeutic strategies. Future multicenter studies are needed to validate our findings.

\section{Conclusions}

our study indicates that EVT for patients with BAO should be reasonable in the modern era despite lack of data from randomized clinical trials to establish the best treatment for BAO.

\section{Supplementary information}

Supplementary information accompanies this paper at https://doi.org/10. 1186/s12883-019-1551-8.

Additional file 1: s1:Comparistions of patients' charactristics between outcomes (mRS 3-6 vs. mRS 0-2). s2:Comparistions of patients' charactristics between $90 \mathrm{~d}$ alive vs. $90 \mathrm{~d}$ death. s3:Comparistions of patients' charac tristics between NO HT within $24 \mathrm{~h}$ vs. HT within 24h. s4:Comparistions of patients' charactristics between poor clooateral vs. good collateral

\footnotetext{
Abbreviations

ACS: Anterior circulation stroke; AIS: Acute ischemic stroke; BAO: Basilar artery occlusion; CT: Computed tomography; CTA: Computed tomography angiography; EVT: Endovascular treatment; EVT: Endovascular treatment; ICAS: Intracranial atherosclerotic stenosis; IQR: Interquartile range; IVT: Intravenous thrombolysis; MRA: Magnetic resonance angiography; MRI: Magnetic resonance imaging; mRS: Modified Rankin Scale; MT: Mechanical thrombectomy; mTICl: Modified Thrombolysis in Cerebral Infarction; NIHSS: National Institutes of Health Stroke Scale; pcASPECTS: Prognosis Early CT Score; PCS: Posterior circulation stroke; $\mathrm{SICH}$ : Symptomatic intracerebral hemorrhage; tPA: Tissue plasminogen activator
}

Acknowledgments

We thank all relevant clinicians, statistician, and imaging technicians. 


\section{Authors' contributions}

X.S. and Z.M. designed research; X.S., X.T., F.G. and H.L. collection and interpretation of data; Z. M designed research, collection, analysis, and interpretation of data. All authors read and approved the final manuscript.

\section{Funding}

This study was funded by the National Key Research and Development Program of China; (2016YFC1301501).

The funding body played no role in the design of the study and collection, analysis, and interpretation of data and in writing the manuscript. All The authors disclosed no financial relationships relevant to this study.

\section{Availability of data and materials}

The datasets used and/or analysed during the current study available from the corresponding author on reasonable request.

\section{Ethics approval and consent to participate}

The protocol was approved by the Institutional Review Board of Beijing Tiantan Hospital. The appropriate permissions to access the patient database which provided the data for our study were granted by Beijing Tiantan Hospital.

\section{Consent for publication}

Not applicable.

\section{Competing interests}

The authors declare no conflict of interest.

\section{Author details}

'Department of Interventional Neurology, Beijing Tiantan Hospital, Capital Medical University, 119 South Fourth Ring West Road, Fengtai District, Beijing, China. ${ }^{2}$ Department of Medicine, Queen Elizabeth Hospital, Hong Kong, China.

Received: 9 May 2019 Accepted: 2 December 2019

Published online: 06 December 2019

\section{References}

1. Schonewille WJ, Wijman CA, Michel P, Rueckert CM, Weimar C, Mattle HP, Engelter ST, Tanne D, Muir KW, Molina CA, Thijs V, Audebert H, Pfefferkorn T, Szabo K, Lindsberg PJ, de Freitas G, Kappelle LJ, Algra A, BASICS study group. Treatment and outcomes of acute basilar artery occlusion in the Basilar Artery International Cooperation Study (BASICS): a prospective registry study. Lancet Neurol. 2009;8:724-30.

2. Schonewille WJ, Algra A, Serena J, Molina CA, Kappelle LJ. Outcome in patients with basilar artery occlusion treated conventionally. J Neurol Neurosurg Psychiatry. 2005;76:1238-41.

3. Saver JL, Jahan R, Levy El, Jovin TG, Baxter B, Nogueira RG, Clark W, Budzik R, Zaidat OO, SWIFT Trialists. Solitaire flow restoration device versus the merc retriever in patients with acute ischaemic stroke (SWIFT): a randomised, parallel-group, non-inferiority trial. Lancet. 2012;380:1241-9.

4. Nogueira RG, Lutsep HL, Gupta R, Jovin TG, Albers GW, Walker GA Liebeskind DS, Smith WS, TREVO 2 Trialists. Trevo versus Merci retrievers for thrombectomy revascularisation of large vessel occlusions in acute ischaemic stroke (TREVO 2): a randomised trial. Lancet. 2012;380:1231-40.

5. Goyal M, Menon BK, van Zwam WH, Dippel DW, Mitchell PJ, Demchuk AM, Dávalos A, Majoie CB, van der Lugt A, de Miquel MA, Donnan GA, Roos YB, Bonafe A, Jahan R, Diener HC, van den Berg LA, Levy El, Berkhemer OA, Pereira VM, Rempel J, Millán M, Davis SM, Roy D, Thornton J, Román LS, Ribó M, Beumer D, Stouch B, Brown S, Campbell BC, van Oostenbrugge RJ, Saver JL, Hill MD, Jovin TG, HERMES collaborators. Endovascular thrombectomy after large-vessel ischaemic stroke: a meta-analysis of individual patient data from five randomised trials. Lancet. 2016:387:1723-31.

6. Bracard S, Ducrocq X, Mas JL, Soudant M, Oppenheim C, Moulin T, Guillemin F, THRACE investigators. Mechanical thrombectomy after intravenous alteplase versus alteplase alone after stroke (THRACE): a randomised controlled trial. Lancet Neurol. 2016;15:1138-47.

7. Glass TA, Hennessey PM, Pazdera L, Chang HM, Wityk RJ, Dewitt LD, Pessin MS, Caplan LR. Outcome at 30 days in the new England Medical Center posterior circulation registry. Arch Neurol. 2002:59:369-76.
8. De Marchis GM, Kohler A, Renz N, Arnold M, Mono ML, Jung S, Fischer U, Karameshev Al, Brekenfeld C, Gralla J, Schroth G, Mattle HP, Nedeltchev K. Posterior versus anterior circulation strokes: comparison of clinical, radiological and outcome characteristics. J Neurol Neurosurg Psychiatry. 2011;82:33-7.

9. Powers WJ, Rabinstein AA, Ackerson T, Adeoye OM, Bambakidis NC, Becker K, Biller J, Brown M, Demaerschalk BM, Hoh B, Jauch EC, Kidwell CS, Leslie-Mazwi TM, Ovbiagele B, Scott PA, Sheth KN, Southerland AM, summers DV, Tirschwell DL, American Heart Association stroke council. 2018 guidelines for the early Management of Patients with Acute Ischemic Stroke: a guideline for healthcare professionals from the American Heart Association/American Stroke Association. Stroke. 2018:49:e46-e110.

10. Adams HP Jr, Bendixen BH, Kappelle LJ, Biller J, Love BB, Gordon DL, Marsh EE 3rd. Classification of subtype of acute ischemic stroke. Definitions for use in a multicenter clinical trial. TOAST. Trial of org 10172 in acute stroke treatment. Stroke. 1993:24:35-41.

11. Goyal N, Tsivgoulis G, Nickele C, Doss VT, Hoit D, Alexandrov AV, Arthur A, Elijovich L. Posterior circulation CT angiography collaterals predict outcome of endovascular acute ischemic stroke therapy for basilar artery occlusion. J Neurointerv Surg. 2016;8:783-6.

12. Singer OC, Berkefeld J, Nolte CH, Bohner G, Haring HP, Trenkler J, Gröschel K, Müller-Forell W, Niederkorn K, Deutschmann H, Neumann-Haefelin T, Hohmann C, Bussmeyer M, Mpotsaris A, Stoll A, Bormann A, Brenck J, Schlamann MU, Jander S, Turowski B, Petzold GC, Urbach H, Liebeskind DS, ENDOSTROKE Study Group. Mechanical recanalization in basilar artery occlusion: the ENDOSTROKE study. Ann Neurol. 2015;77:415-24.

13. Zaidat OO, Yoo AJ, Khatri P, Tomsick TA, von Kummer R, Saver JL, Marks MP Prabhakaran S, Kallmes DF, Fitzsimmons BF, Mocco J, Wardlaw JM, Barnwell SL, Jovin TG, Linfante I, Siddiqui AH, Alexander MJ, Hirsch JA, Wintermark M, Albers G, Woo HH, Heck DV, Lev M, Aviv R, Hacke W, Warach S, Broderick J, Derdeyn CP, Furlan A, Nogueira RG, Yavagal DR, Goyal M, Demchuk AM, Bendszus M, Liebeskind DS, Cerebral Angiographic Revascularization Grading (CARG) Collaborators, STIR Revascularization working group, STIR Thrombolysis in Cerebral Infarction (TICl) Task Force. Recommendations on angiographic revascularization grading standards for acute ischemic stroke: a consensus statement. Stroke. 2013:44:2650-63.

14. Hacke W, Kaste M, Bluhmki E, Brozman M, Dávalos A, Guidetti D, Larrue V, Lees KR, Medeghri Z, Machnig T, Schneider D, von Kummer R, Wahlgren N, Toni D, ECASS investigators. Thrombolysis with alteplase 3 to 4.5 hours after acute ischemic stroke. N Engl J Med. 2008;359:1317-29.

15. Alawieh A, Vargas J, Turner RD, Turk AS, Chaudry MI, Lena J, Spiotta A. Equivalent favorable outcomes possible after thrombectomy for posterior circulation large vessel occlusion compared with the anterior circulation: the MUSC experience. J Neurointerv Surg. 2018;10:735-40.

16. Yoon W, Kim SK, Heo TW, Baek BH, Lee YY, Kang HK. Predictors of good outcome after stent-retriever Thrombectomy in acute basilar artery occlusion. Stroke. 2015:46:2972-5.

17. Lee YY, Yoon W, Kim SK, Baek BH, Kim GS, Kim JT, Park MS. Acute basilar artery occlusion: differences in characteristics and outcomes after endovascular therapy between patients with and without underlying severe atherosclerotic stenosis. AJNR Am J Neuroradiol. 2017;38:1600-4.

18. Kang DH, Jung C, Yoon W, Kim SK, Baek BH, Kim JT, Park MS, Kim YW, Hwang YH, Kim YS, Kim BJ, Han MK, Bae HJ. Endovascular Thrombectomy for acute basilar artery occlusion: a multicenter retrospective observationa study. J Am Heart Assoc. 2018;7.

19. Li C, Zhao W, Wu C, Shang S, Chen J, Ren M, Duan J, Ma Q, Li G, Zhang Y, Zhang $\mathrm{H}$, Jiao L, Ji X. Outcome of endovascular treatment for acute basilar artery occlusion in the modern era: a single institution experience. Neuroradiology. 2018:60:651-9.

20. Bouslama M, Haussen DC, Aghaebrahim A, Grossberg JA, Walker G, Rangaraju S, Horev A, Frankel MR, Nogueira RG, Jovin TG, Jadhav AP. Predictors of good outcome after endovascular therapy for Vertebrobasilar occlusion stroke. Stroke. 2017:48:3252-7.

21. Gory B, Mazighi M, Blanc R, Labreuche J, Piotin M, Turjman F, Lapergue B. Mechanical thrombectomy in basilar artery occlusion: influence of reperfusion on clinical outcome and impact of the first-line strategy (ADAPT vs stent retriever). J Neurosurg. 2018;129:1482-91.

22. Giorgianni A, Biraschi F, Piano M, Mardighian D, Gasparotti R, Frigerio M, Pero G, Quilici L, Crispino M, Pellegrino C, Pavia M, Peroni R, Longoni M, Cellerini M, Lafe E, Remida P, Faragò G, Reganati P, Strocchi S, Valvassori L. 
Endovascular treatment of acute basilar artery occlusion: Registro Endovascolare Lombardo Occlusione basilar artery (RELOBA) study group experience. J Stroke Cerebrovasc Dis. 2018;27:2367-74.

23. Gory B, Eldesouky I, Sivan-Hoffmann R, Rabilloud M, Ong E, Riva R, Gherasim DN, Turjman A, Nighoghossian N, Turiman F. Outcomes of stent retriever thrombectomy in basilar artery occlusion: an observational study and systematic review. J Neurol Neurosurg Psychiatry. 2016;87:520-5.

24. Mokin M, Sonig A, Sivakanthan S, Ren Z, Elijovich L, Arthur A, Goyal N, Kan P, Duckworth E, Veznedaroglu E, Binning MJ, Liebman KM, Rao V, Turner RD 4th, Turk AS, Baxter BW, Dabus G, Linfante I, Snyder KV, Levy El, Siddiqui AH. Clinical and procedural predictors of outcomes from the endovascular treatment of posterior circulation strokes. Stroke. 2016;47:782-8.

25. Broeg-Morvay A, Mordasini P, Bernasconi C, Bühlmann M, Pult F, Arnold M, Schroth G, Jung S, Mattle HP, Gralla J, Fischer U. Direct mechanical intervention versus combined intravenous and mechanical intervention in large artery anterior circulation stroke: a matched-pairs analysis. Stroke. 2016:47:1037-44.

26. Cohen JE, Leker RR, Gomori JM, Eichel R, Rajz G, Moscovici S, Itshayek E. Emergent revascularization of acute tandem vertebrobasilar occlusions: endovascular approaches and technical considerations-confirming the role of vertebral artery ostium stenosis as a cause of vertebrobasilar stroke. J Clin Neurosci. 2016:34:70-6.

27. Caplan LR, Amarenco P, Rosengart A, Lafranchise EF, Teal PA, Belkin M, DeWitt LD, Pessin MS. Embolism from vertebral artery origin occlusive disease. Neurology. 1992;42:1505-12.

28. Gao F, Lo WT, Sun X, Mo DP, Ma N, Miao ZR. Combined use of mechanical Thrombectomy with angioplasty and stenting for acute basilar occlusions with underlying severe intracranial Vertebrobasilar stenosis: preliminary experience from a single Chinese center. AJNR Am J Neuroradiol. 2015;36:1947-52.

29. Yoon W, Kim SK, Park MS, Kim BC, Kang HK. Endovascular treatment and the outcomes of atherosclerotic intracranial stenosis in patients with hyperacute stroke. Neurosurgery. 2015;76:680-6 discussion 686.

30. Kim SK, Yoon W, Moon SM, Park MS, Jeong GW, Kang HK. Outcomes of manual aspiration thrombectomy for acute ischemic stroke refractory to stent-based thrombectomy. J Neurointerv Surg. 2015;7:473-7.

31. Berkhemer OA, Jansen IG, Beumer D, Fransen PS, van den Berg LA, Yoo AJ, Lingsma HF, Sprengers ME, Jenniskens SF, Nijeholt GJ LÀ, van Walderveen $M A$, van den Berg $R$, Bot JC, Beenen LF, Boers AM, Slump CH, Roos YB, van Oostenbrugge RJ, Dippel DW, van der Lugt A, van Zwam WH, Marquering HA, Majoie CB, MR CLEAN Investigators. Collateral Status on Baseline Computed Tomographic Angiography and Intra-Arterial Treatment Effect in Patients With Proximal Anterior Circulation Stroke. Stroke. 2016;47:768-76.

32. Bang OY, Saver JL, Kim SJ, Kim GM, Chung CS, Ovbiagele B, Lee KH, Liebeskind DS. Collateral flow predicts response to endovascular therapy for acute ischemic stroke. Stroke. 2011;42:693-9.

33. Jovin TG, Gupta R, Horowitz MB, Grahovac SZ, Jungreis CA, Wechsler L, Gebel JM, Yonas H. Pretreatment ipsilateral regional cortical blood flow influences vessel recanalization in intra-arterial thrombolysis for MCA occlusion. AJNR Am J Neuroradiol. 2007;28:164-7.

\section{Publisher's Note}

Springer Nature remains neutral with regard to jurisdictional claims in published maps and institutional affiliations.

Ready to submit your research? Choose BMC and benefit from:

- fast, convenient online submission

- thorough peer review by experienced researchers in your field

- rapid publication on acceptance

- support for research data, including large and complex data types

- gold Open Access which fosters wider collaboration and increased citations

- maximum visibility for your research: over $100 \mathrm{M}$ website views per year

At $\mathrm{BMC}$, research is always in progress.

Learn more biomedcentral.com/submissions 